\title{
Landscape changes based on sedimentological and geochemical studies in the region of Brudzeń Duży
}

\begin{abstract}
Sedimentological and geochemical research carried out in NorthWest Mazovia, central Poland, allowed the determination of landscape transformation in relation to the history of human settlement. The types of sediments subject to analysis included palaeochannel filling, accumulation on the river floodplain and colluvial deposits. The absolute ages of sediments and their sedimentological features allow the conclusion that the first response to human activity in the area is recorded in the overbank deposits in the Skrwa River valley as a result of the Wielbarska Culture in 200-300 AD. Subsequently, fan accumulation at the mouths of gullies started around the $12^{\text {th }}-13^{\text {th }}$ centuries AD. Frequent changes of sediment properties have been observed since the early Middle Ages. The subsequent anthropogenic impact on homogenous deposits is recorded in increased heavy metal concentration in vertical geological profiles.
\end{abstract}

\section{Keywords}

Geomorphology • alluvium • colluvium • human impact • gully formation • sedimentation rates $\cdot$ Northern Poland

(C) University of Warsaw - Faculty of Geography and Regional Studies

\author{
Ewa Smolska1 \\ Piotr Szwarczewski \\ 'Department of Geomorfology \\ Institute of Physical Geography \\ Faculty of Geography and Regional Studies, \\ University of Warsaw \\ e-mail: e.smolska@uw.edu.pl \\ ${ }^{2}$ Department of Geomorfology \\ Institute of Physical Geography \\ Faculty of Geography and Regional Studies, \\ University of Warsaw \\ e-mail: pfszwarc@uw.edu.pl \\ Received: 6 November 2013 \\ Accepted: 30 December 2013
}

\section{Introduction}

Recently, research on late Holocene fluvial, colluvial or lacustrine deposits has gained popularity. Based on the characteristics of these sediments, conclusions regarding denudation and sedimentation depending on climate may be drawn. These geomorphological processes were also accelerated due to anthropogenic pressure, accompanied by increasing local changes - land use and the landscape modification of substantial areas (Starkel 1989; 2005; Lang 2003; Zolitschka et al. 2003; Klimek, 2003, Stankoviansky 2003). Such changes have been described for a number of locations in Poland (Sinkiewicz 1998; Twardy 1995; Kalicki 2006; Smolska 2007; Szpikowski 2010), including in Mazovia (Szwarczewski 2005; 2009). Quite often, the special role of anthropogenic impact on the natural environment has been pointed out with reference to archaeological research (Niewiarowski 1995; Kittel et al. 2008; Hildebrandt-Radke 2010). Northern Mazovia has lacked in-depth studies in this respect.

The research carried out in the region had the purpose of analysing sediments of different deposits and relating sediment properties to the development of human settlement. In the Skrwa River valley near Brudzeń Duży village the sedimentological and geochemical characteristics of sediments were analysed in order to reconstruct natural environment changes resulting from anthropogenic impact. Some results of these analyses have already been published (Smolska, Szwarczewski 2012).

\section{Research area}

The sedimentological and geochemical studies were carried out in a site located in the north-western part of the Mazovia region, near the village of Brudzeń Duży (N5240’5.5”; E19³0'4”) in central Poland (Fig. 1). It is located within the reach of the Last Glacial Maximum (LGM) and includes a section of the Skrwa River valley surrounded by a moraine plateau and outwash plains.

The Skrwa River valley is approximately $200 \mathrm{~m}$ wide and is incised 15-20 m into a moraine plateau and outwash plain. This valley has steep slopes, with local inclination ranging from $12^{\circ}$ to over $20^{\circ}$. The moraine plateau and outwash plain in the vicinity are used as arable land, while the valley bottom holds grassland. The slopes are permanently covered with grass, and the area between Brudzeń Duży and Parzeń is forested. The moraine plateau and outwash plains are characterized by undulations, with mild slope inclination ranging from $3^{\circ}$ to $6^{\circ}$. Gullies are cut into the valley slopes. Their cross-section is v-shaped and the longitudinal profile fairly even. Some of them are used as access roads to meadows, and have thus been transformed into gullies. The v-shaped gullies are not very deep (2-3 $\mathrm{m})$; the gullies used as a road are deeper (up to $7 \mathrm{~m}$ ) (Photo 1A, B). The research was concentrated on the sediments building the valley bottom: fluvial terraces, a filling of selected paleomeanders and fans at the mouths of the gullies.

\section{Research methods}

Interdisciplinary methodologies were applied to achieve the previously stated objective. The first stage included a general geomorphological mapping of the area and recognition of forms and sediments characteristic for the selected sites. Archaeological data were analysed, including the Project of the Archaeological Picture of Poland (AZP) and publications allowing 

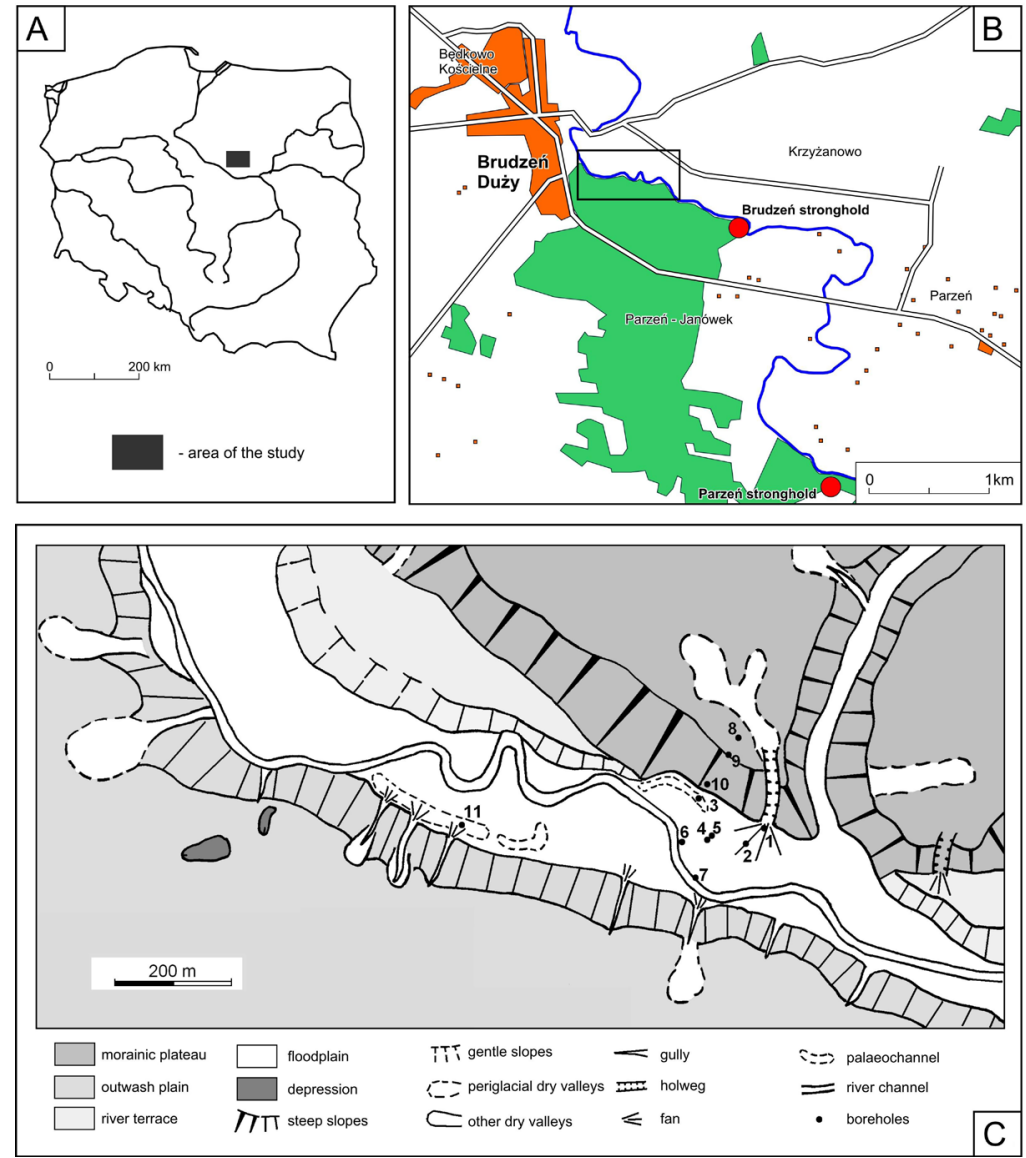

Figure 1. Location of study area and geomorphological scheme of the Brudzeń Duży area with location of boreholes

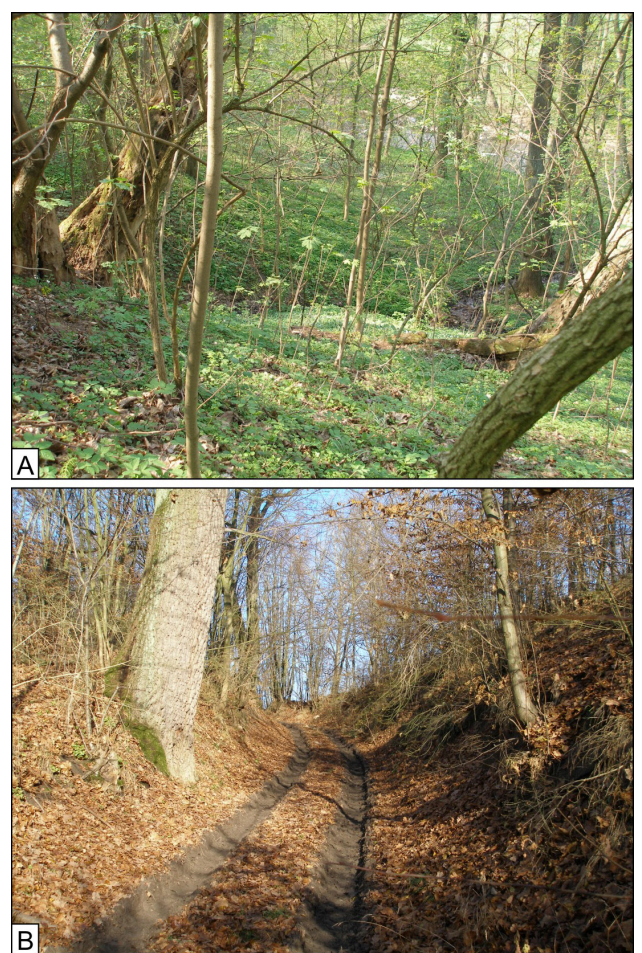

Photo 1. Gullies on the southern (A) and northern (B) slopes of the Skrwa valley the settlement history in the examined area to be determined (Kaczanowski \& Kozłowski 1998).

Drillings were taken in order to analyse the lithology of different deposits and to obtain samples for laboratory analyses. Sediment cores with a depth of up to $4.5 \mathrm{~m}$ were taken with the use of a hand gouge auger for mineral and mineral/organic sediments, and with an Instorf auger for peat. Sediment cores were collected with preserved stratigraphy and analysed macroscopically in vertical profiles. There were no clearly visible gaps, and therefore the continuity of the sedimentary record was assumed. All macroscopic visible layers and horizons were described during fieldwork.

Samples for grain size analysis were taken from each determined layer. For other analyses, samples were taken with $5-10 \mathrm{~cm}$ frequency depending on the variability of the vertical sediment profile.

Laboratory analyses included the determination of the organic matter content by "Ioss-on-ignition" (LOI) and the Scheibler method to determine the carbonate content. Grain size distribution was determined by a combination of sieving and the aerometric method. Grain size indexes were calculated according to Folk and Ward (1957). Chemical analyses included the determination of the content of selected trace elements in the sediments. The extraction was carried out with aqua fortis and the concentrations were determined by ICP MS.

The age of organic sediments was determined by radiocarbon dating. The obtained dates were calibrated with the use of OxCal v. 4.2.3 (Ramsey at al. 2013; Reimer et al. 2013). 

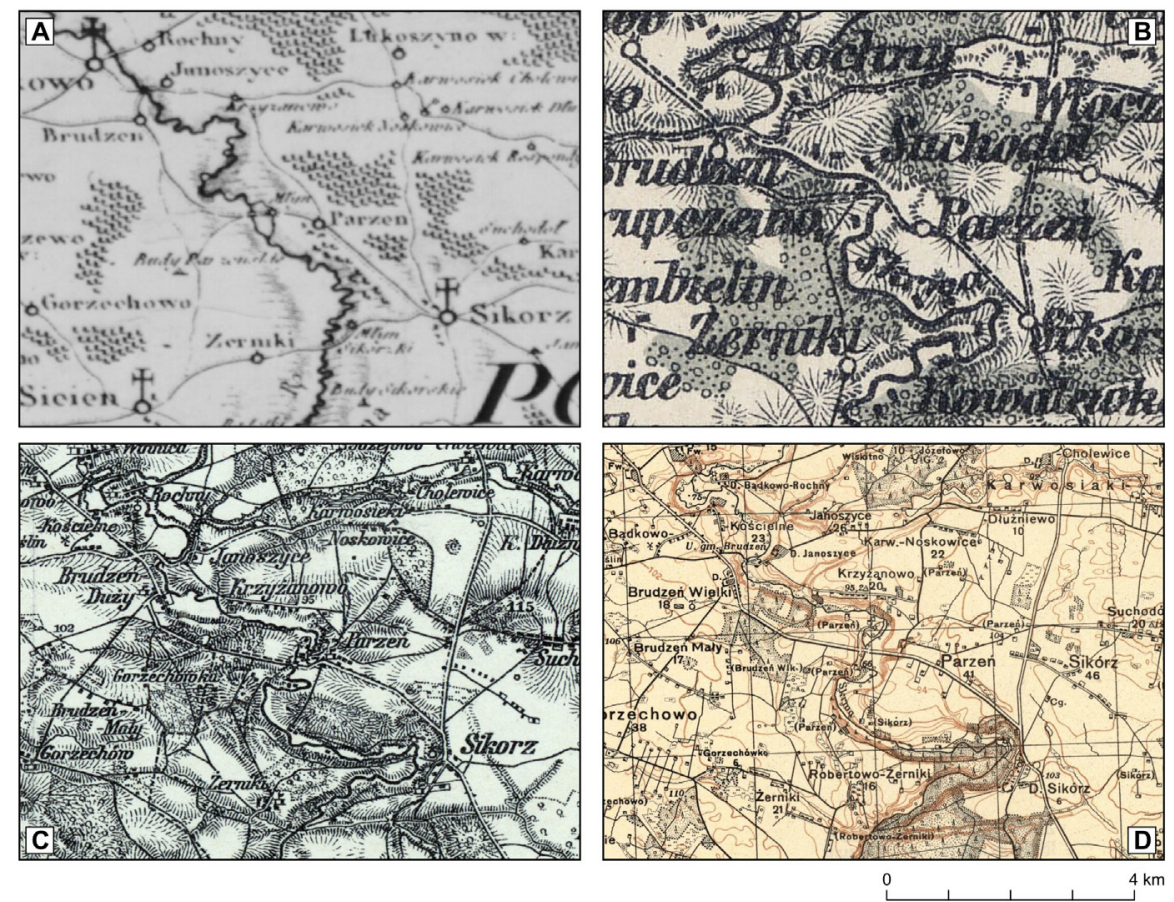

Figure 2. Selected historical maps presenting the area of the study. A. 1802 AD - Mapa Szczegulna Województwa Płockiego $i$ Ziemi Dobrzynskiey Karola de Perthesa, $1: 225$ 000, B. 1873 AD - General Karte von Central Europa, $1: 300$ 000, Nowogeorgiewsk, C. 1915 AD - Karte des Westlichen Russlands, 1: 100 000, E 31. Płock, D. 1930 AD - Mapa Taktyczna Polski WIG, 1 : 100 000, P38 S29 Płock

Human settlement stages in the examined area

In the northern part of Mazovia, different phases of human settlement have been identified. Paleolithic and Mesolithic evidence of human presence is distributed in the area and indicate gathering and hunting activities, but only the presence of the well-developed agricultural culture of the middle and late Neolith period, represented by Funnel Beaker (TRB) and Globular Amphorae culture (GAC) (approx. 5-6,000 cal. years BP), was significant for local environmental changes (Kaczanowski, Kozłowski 1998; Matusiak 2008).

In the examined area, the evidence of human presence is also known for the older Bronze Age (Trzciniec culture) and in relation to the Lusatian culture including the late Bronze and early Iron Ages. During the Roman era, north Mazovia was influenced by the Pomeranian stone cist, and the Przeworsk and Wielbark cultures.

Human settlement in northern Mazovia did not become stable and permanent until the early Middle Ages. The areas of Płock and Sierpc were the first to be inhabited by Slavs. Two Slavic strongholds in Brudzeń Duży dating from the $8^{\text {th }}$ and 10$11^{\text {th }}$ centuries and in Parzen dating from the $12^{\text {th }}$ century (Górska et al. 1976) are located at a distance of less than $1 \mathrm{~km}$ from the study site.

Towards the late Middle Ages, the human settlement network in Poland stabilized and permanent administrative structures developed, supported by a growing population and the effects of human pressure on the environment. In general, it may be assumed that during the last millennium the population density has steadily increased, with certain periods of reduction, for example related to wars, or epidemics that occurred in this part of Poland.

Archaeological data indicate that, from the $8^{\text {th }}$ and particularly from the $10-11^{\text {th }}$ centuries, economic development began to increase. The study area was in the centre of this region.
At those times there was an intensive development of crafts such as tanning, metal production and blacksmithing. The following 300 -year-long period is characterized by different wars (Lithuanian raids, the war with the Teutonic Knights, the Swedish Deluge) as well as epidemic events. In the 17th century, there was a little more forest here than in previous periods due to a population decline (Matusiak 2008; Buko 2005). The region was mainly used for agriculture - there were no industrial centres. The closest, located within a radius of $40 \mathrm{~km}$ from the studied area centres are Płock, Włocławek and Sierpc.

The oldest archival maps show significant deforestation of the study area (Fig. 2). In the $19^{\text {th }}$ century, there were forested outwash plains located to the south and west of the Skrwa River valley.

\section{Selected results of the sedimentological research}

The part of the Skrwa River valley selected for the study is characterized by active slope processes (soil erosion, gullying) and fluvial processes with aggradation prevailing on the valley bottom. It includes morphological (landscape) zones of differing sediment type, intensity of geomorphological processes and source of material:

- morainic plateaus and slopes: denudation

- linear erosion on the slopes with deposition on the bottom of the valley: gullying

- fluvial with flood plain, paleomeanders within the plan and point bars: fluvial deposition.

Sheet erosion is the key process forming the moraine plateau and outwash plains used as arable land with periodic tendencies to create shallow gullies. On the domed uplands, luvisol soils with Ap horizons are dominant. The Bt horizon of these soils is characterized by a reduced thickness. 


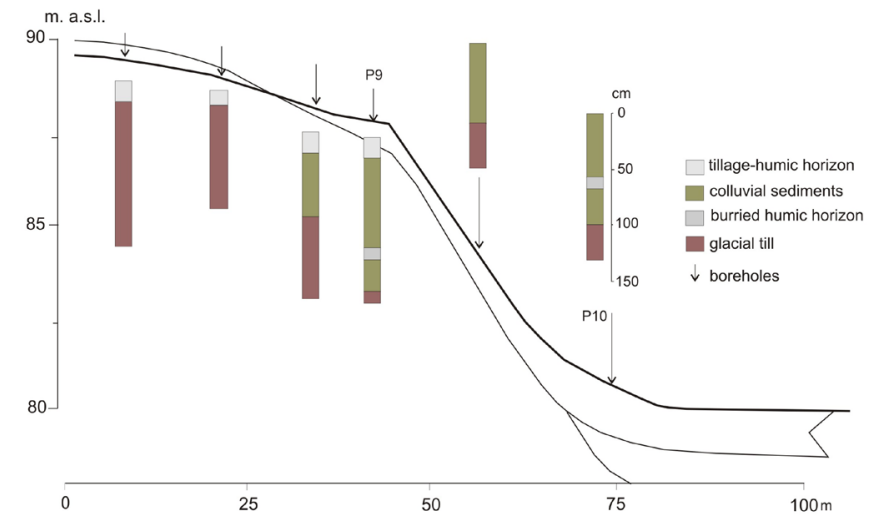

Figure 3. Longitudinal profile of the Skrwa River valley (with moraine plateau in the upper part); $P 8$ and P10 - vertical profiles analysed in detail (for location, see Fig. 1)

The soil erosion process is illustrated by drillings taken along the slope catena selected for detailed examination (Fig. 3). Below the domed upland, on a slope with a 6-70 inclination, directly under the arable humus layer, there is carbonate containing clayey and silty glacial till (drilling P8 on Fig. 3).

The eroded soil was accumulated along the upper rim of the Skrwa River valley. Above the rim (P9, Fig. 3), humic colluvial sediments reach $150 \mathrm{~cm}$ in thickness, and up to $110 \mathrm{~cm}$ in depth. The LOI ranges from 2.0 to $3.8 \%$, while below it reaches $1-2$ $\%$. Humic colluvial sediment thickness reaches $90-100 \mathrm{~cm}$ in the middle part of the slope. On the lower part of the valley slope the colluvium reaches $130 \mathrm{~cm}$ in thickness with maximum LOI exceeding $5 \%$.

Such redeposition of the eroded soil is most probably caused by the complex morphology of the slope being used. The lesserinclined slope is used as arable land, while the steeper parts are permanently covered by grasslands. The upper edge of the valley is at the same time the border of the arable land. Since the reversible plough was introduced, in particular the drill plough, an agricultural terrace has been formed here. The accumulated material is homogeneous due to mixing during ploughing (Sinkiewicz 1998).

Colluvial sediments deposited on the lower part of the valley slope cause a decrease in inclination to $3-4^{\circ}$ (Fig. 3).

From the gullies cutting the slopes, two forms have been selected for detailed examination: a road gully near Krzyżanowo village, located on the northern slope of the valley, and a v-shaped gully located on the southern forested slope, to the east of Brudzeń Duży (Fig. 1).

The first form is located in the lower part of a substantially incised dry valley. The gully is approximately $110 \mathrm{~m}$ long, with steep slopes, whose inclination reaches locally up to $70^{\circ}$. At the mouth of the gully, there is a fan of over $80 \mathrm{~m}$ long. The accumulated sediments are not very thick, reaching $120 \mathrm{~cm}$ in the proximal and $70 \mathrm{~cm}$ in the distal part of the fan, and are composed of massive clayey sands of varying grain size with the addition of humus-like organic matter (3-5\%).

Two units are visible in the sediment constituting the fan: the upper measures up to $40 \mathrm{~cm}$ in depth and the lower measures from 40 to $120 \mathrm{~cm}$ in depth. The upper part of the fan shows characteristics of colluvial deposits from soil erosion; the lower part consists both of the products of soil erosion and those from incision of the clayey moraine plateau (the widening and deepening of the gully). The two units are diversified in granulometry. The sediments accumulated in the upper part of the fan (upper unit) are rather homogenous and consist of sand, silt and clay with a high content of organic matter (3-5\% LOI). The lower one is more diversified in granulometry. It consists generally of sands with an admixture of fine gravels (single grains with diameter ranging from 5 to $20 \mathrm{~mm}$, usually a few percent of the sediment mass) and clays (several percent). The clayey sediments most probably originate from the gully bottom and slopes, where glacial till occurs. Detailed sedimentological characteristics of the fan sediments have already been described in detail (Smolska \& Szwarczewski 2012).

The vertical profile of the fan deposits, in the proximal part, includes two humic horizons with a higher content of organic matter (3.7 to $3.8 \%$ ): one at the bottom of the fan, the other at a depth of $70-80 \mathrm{~cm}$. The lower one (with $3.8 \%$ organic matter content) has been dated with the radiocarbon method to 206BC$645 \mathrm{AD}$ and indicates the beginning of the fan formation.

The fan selected for detailed examination on the opposite side of the valley is short but well exposed, located at the mouth of a v-shaped gully (Fig. 1). It covers sediments of a former paleomeander located at the bottom of the slope (Fig. 4). The thickness of the fan sediments approximates $70 \mathrm{~cm}$. It consists of sand of diverse grain size with the addition of silt (about $20 \%$ ) and clay $(10 \%)$. The grain-size distribution is characterized by weak sorting, a significantly positive skew. The LOI values range from 2.5 to $4 \%$ (Smolska \& Szwarczewski 2012).

Similarly to the fan examined at the gully mouth near Krzyżanowo, the lower part is more diversified in granulometry. Both upper and lower series are similar to those determined in the fan near Krzyżanowo.

Layers which comprise deposits that fill the paleomeander were drilled up to a depth of $250 \mathrm{~cm}$. The bottom $50 \mathrm{~cm}$ series consists of organic mud accumulated in the old meander. Above this, at 200-160 cm, there are laminated sandy deposits with a much lower content of organic matter, indicating a period of water flow in the meander. This layer, in turn, is topped with accumulated organic matter (at 160-70 cm) with irregular mineral interbedding, mainly comprising fine-grain deposits classified as over channel alluvia.

The organic matter from the roof of the organic series filling the bottom of the paleomeander and the basis of the fan was dated using the radiocarbon method (Table 1). The results indicate that the old meander became active and the fan started to form at the gully mouth around 208-545AD and 1040-1285AD, respectively.

A second paleomeander at the northern slope of the valley, west of Krzyżanowo, was also sampled (P3, Fig. 1).

At $420 \mathrm{~cm}$, there is a layer of till, in which the Skrwa channel was probably cut. The deposits in the paleomeander start with a sandy series with a small content of fine gravel (up to $365 \mathrm{~cm}$ deep). This is a point bar. Above, ranging from 365 to $300 \mathrm{~cm}$, the meander is filled with sandy silt containing from 17 to 30 percent organic 

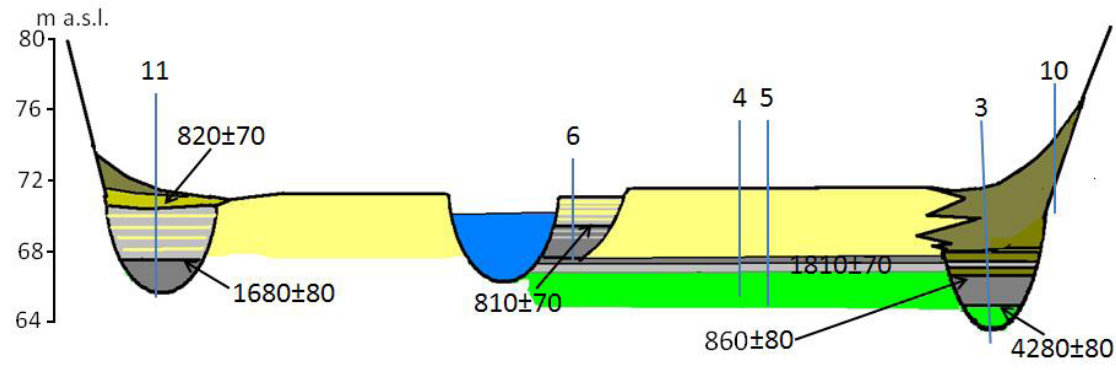

channel alluvia overbank alluvia organic matter

$50 \mathrm{~m}$ colluvium from gullying

Figure 4. Schematic geological cross-section through the Skrwa River valley between Brudzeń Duży and Krzyżanowo: 1-11 - boreholes

Table 1. Radiocarbon dating; calibration with the OxCal v. 4.2.3. (Ramsey at al. 2013, atmospheric data from Reimer et al. 2013)

\begin{tabular}{|c|c|c|c|c|c|}
\hline Profile & Material & $\begin{array}{l}\text { Sampling } \\
\text { depth }[\mathrm{cm}]\end{array}$ & $\begin{array}{l}{ }^{14} \mathrm{C} \text { age } \mathrm{BP}, \\
\text { lab. code }\end{array}$ & $\begin{array}{c}1 \text { sigma } \\
(68.2 \% \text { probability) }\end{array}$ & $\begin{array}{c}2 \text { sigma } \\
\text { (95.4\% probability) }\end{array}$ \\
\hline 6 & $\begin{array}{l}\text { Organic } \\
\text { mud }\end{array}$ & $110-115$ & $\begin{array}{c}810 \pm 70 \\
\text { MKL-920 }\end{array}$ & 1162AD (68.2\%) 1274AD & $\begin{array}{l}\text { 1040AD }(13.3 \%) \text { 1110AD } \\
\text { 1116AD }(82.1 \%) \text { 1290AD }\end{array}$ \\
\hline 11 & $\begin{array}{l}\text { Organic } \\
\text { mud }\end{array}$ & $65-70$ & $\begin{array}{l}820 \pm 70 \\
K L-921\end{array}$ & 1156AD (68.2\%) 1275AD & 1040AD (95.4\%) 1285AD \\
\hline 4 & Peat & $300-305$ & $\begin{array}{c}860 \pm 80 \\
\text { VS-2003 }\end{array}$ & $\begin{array}{c}\text { 1049AD }(14.3 \%) \text { 1084AD } \\
\text { 1124AD }(4.5 \%) \text { 1136AD } \\
\text { 1150AD }(49.3 \%) \text { 1256AD }\end{array}$ & 1025AD (95.4\%) 1275AD \\
\hline 11 & Peat & $200-210$ & $\begin{array}{r}1680 \pm 80 \\
M K L-923\end{array}$ & $\begin{array}{l}245 \mathrm{AD}(66.5 \%) \text { 428AD } \\
\text { 498AD }(1.7 \%) 505 \mathrm{AD}\end{array}$ & $\begin{array}{l}\text { 140AD }(4.4 \%) \text { 196AD } \\
208 A D(91.0 \%) 545 A D\end{array}$ \\
\hline 1 & Soil organic & $115-120$ & $\begin{array}{l}1790 \pm 200 \\
\text { VS-2001 }\end{array}$ & $\begin{array}{l}2 A D(65.3 \%) 430 A D \\
493 A D(1.8 \%) 510 A D \\
517 A D(1.2 \%) 528 A D\end{array}$ & $\begin{array}{l}346 \mathrm{BC}(0.8 \%) 320 \mathrm{BC} \\
206 \mathrm{BC}(94.6 \%) 645 \mathrm{AD}\end{array}$ \\
\hline 4 & $\begin{array}{l}\text { Organic } \\
\text { mud }\end{array}$ & $215-220$ & $\begin{array}{l}1810 \pm 70 \\
\text { VS-2002 }\end{array}$ & $\begin{array}{l}127 \mathrm{AD}(53.9 \%) 260 \mathrm{AD} \\
280 \mathrm{AD}(14.3 \%) 324 \mathrm{AD}\end{array}$ & 66AD (95.4\%) 384AD \\
\hline 3 & Peat & $350-355$ & $\begin{array}{l}4280 \pm 80 \\
M K L-923\end{array}$ & $\begin{array}{l}\text { 3022BC }(53.0 \%) 2861 \mathrm{BC} \\
2808 \mathrm{BC}(12.4 \%) 2756 \mathrm{BC} \\
2719 \mathrm{BC}(2.8 \%) 2705 \mathrm{BC}\end{array}$ & $\begin{array}{l}3264 \mathrm{BC}(1.0 \%) 3241 \mathrm{BC} \\
3104 \mathrm{BC}(94.4 \%) 2620 \mathrm{BC}\end{array}$ \\
\hline
\end{tabular}

matter. The bottom and top of the series were radiocarbon-dated to 3104BC-2620BC and 1025AD-1275AD respectively (Table 1). The dates indicate that the meander was cut off at the beginning of the Subboreal and that the subsequent organic and organic/ mineral sedimentation occurred for nearly 3,500 years. From 1025-1275 AD, the sedimentation changed to mineral, loamy sand. The content of organic matter is substantially reduced and ranges from 2 to 8 percent. The sediment is characterized by a high percentage of fine-grain fractions (50 to 60 percent of silt and clay) and some gravel ( 0.5 to 2 percent) including single gravel grains up to $2 \mathrm{~cm}$ in diameter. In the first stage following the change in sedimentation (at a depth of $300-310 \mathrm{~cm}$ ) the share of fine fractions reached as high as 70 percent. Fine sediments were delivered to the palaeomeander by flood water as well as directly from the Skrwa valley slopes. Beginning from a depth of $120 \mathrm{~cm}$, sandy and clayey alluvia occur, originating from soil erosion caused by sheet erosion, since no flood water reached it.

Similar deposit sequences were found in the meander located near the Skrwa channel (P6, Fig. 1b). It comprised two series: the lower, with organic matter prevailing, and the upper, dominated by mineral deposits (Fig. 3). The change in sedimentation occurred at a similar time, i.e. 1116AD-1290AD.

Two boreholes were made in order to analyse the flood terrace structure between the meanders (P4 and P5, Fig. 1). Up to a depth of $215 \mathrm{~cm}$, alluvial soil made of sand, loam and silt occurs (Fig. 3). The deposit is massive, and least sorted in the bottom part. Higher up, it includes less clay and silt fractions. Accumulated organic matter (15 percent of loss-on-ignition) underlies the alluvial soil with thinly laminated sand and loamy sand. The age of the top part was determined at $1810 \pm 70$ BP. Deeper (below $270 \mathrm{~cm}$ ) there lie point bars, typical for meandering rivers with moraine residuum as the fluvial lag $(300-320 \mathrm{~cm}$ deep).

Geochemical characteristics of deposits

The vertical profiles of the examined Skrwa River valley deposits indicate a number of more or less visible levels of concentrated elements related to changes in the land use and supply of trace metals (Fig. 5).

The first geochemical evidence of human activity dates from the Wielbark (Przeworsk) culture synchronous to the Roman 
A

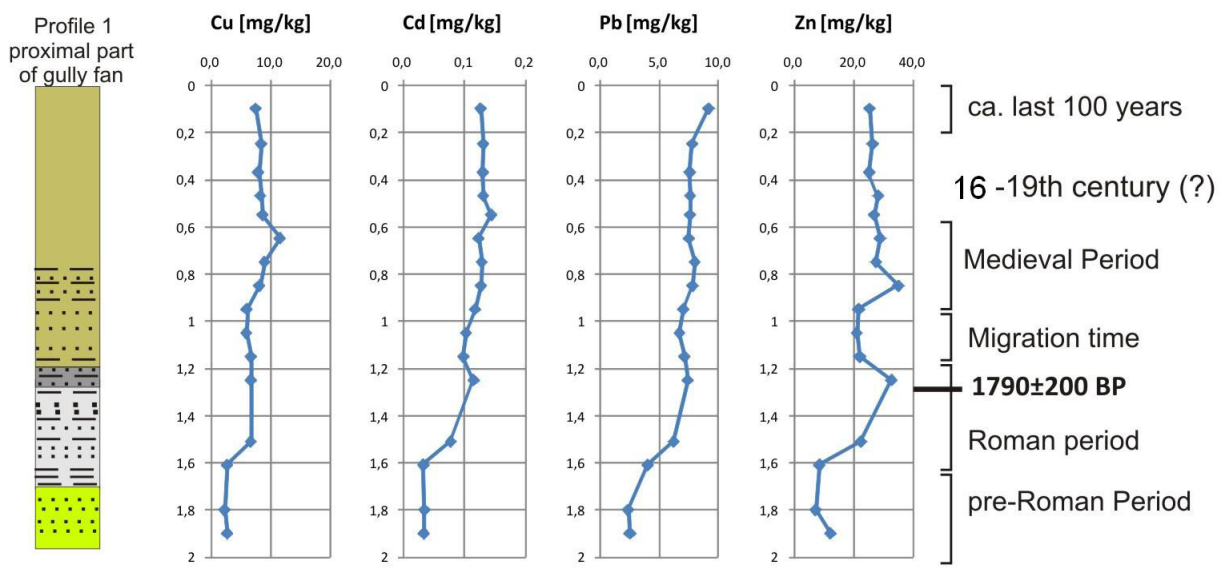

B
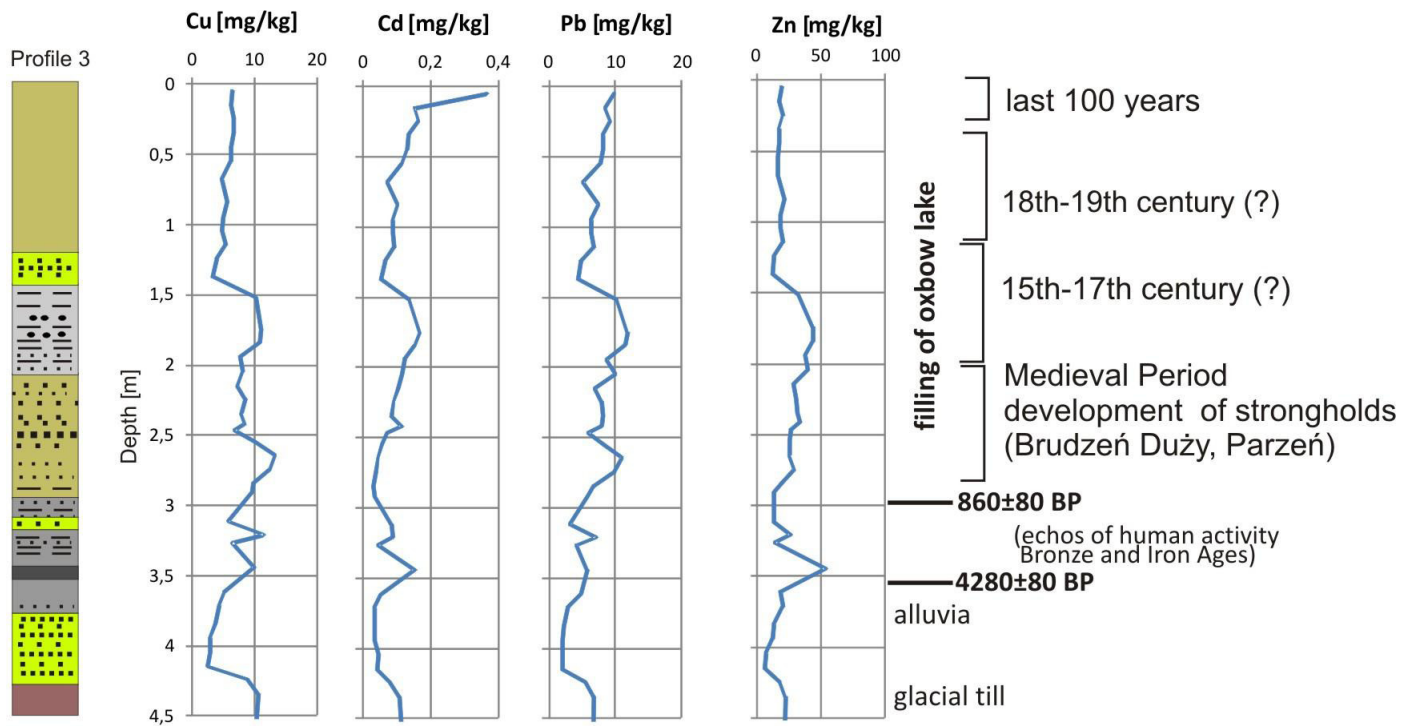

$$
4,5
$$
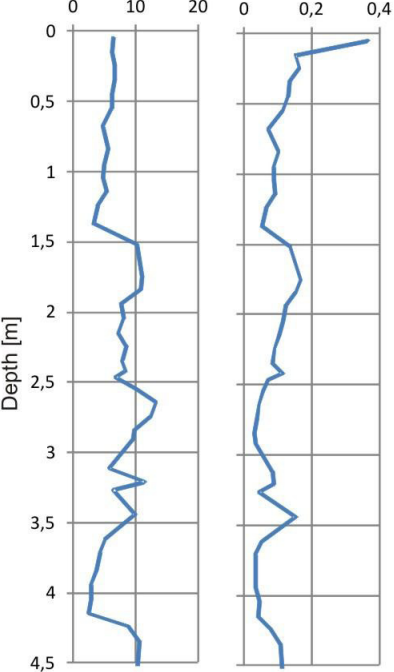

1

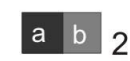

3
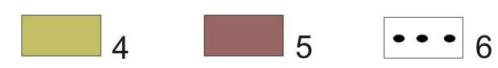

Figure 5. Selected trace element content in sediments building the fan at the mouth of the road ravine (boreholes 1) (A) and filling the palaeochannel (boreholes 3) (B) near Krzyżanowo together with lithological profiles; 1 - channel sands (alluvia), 2 - peat (a) and organic mud (b), 3 - fine sediment with organic matter (overbank alluvia), 4 - colluvium, 5 - glacial till, 6 charcoal; for sampling location see Fig. 1

period (ca. 2000-2400 cal. BP). The geochemical profile of deposits sampled near Krzyżanowo (borehole 1) bears clear evidence of anthropopressure (increased concentration of trace elements) related to the development of the fan accumulated at the mouth of the road gully descending to the river valley.

Its development stages are enhanced by increases or decreases in the content of each element. The radiocarbon date (206BC-645AD) and analysis of economic growth based on archaeological and historical data regarding this part of Mazovia allow several stages of human activity in the examined area to be determined. The interpretation is not solely based on the total content of trace elements at each level, but also on visible trends and their changes (increase, decrease, monotonic course) and the type of sediments (lithological - granulometric features).

The progressing anthropopressure is also illustrated by the reduced content of elements in the upper layers; such a trend has been observed in several profiles characterized by the rapid increase of accumulation of deposits originating from fluvial erosion and slopes (Farkasa et al. 2007). This can be accredited to accelerated erosion and the dilution of pollutants by the supply of unpolluted, clean sediments.

Pollutants that get into the Skrwa River from the Brudzen area were relatively few while those coming from longer distances reached the area in rather small concentrations due to dilution. Increased concentrations of heavy metals are primarily the result of the supply from atmospheric dispersed sources such as the combustion of wood and then coal, mainly for heating, and from the use of fertilizers during cultivation. In the Middle Ages, this was a region of significant economic development, with craft activity such as tanning or blacksmithing.

Despite the generally growing supply of pollutants (on the slopes and into the channels) arising from increasing human 
MISCELLANEA GEOGRAPHICA - REGIONAL STUDIES ON DEVELOPMENT

Vol. $18 \cdot$ No. $1 \cdot 2014 \cdot$ pp. 52-60 •ISSN: 2084-6118 • DOI: 10.2478/mgrsd-2014-0005

Table 2. Calculation of deposition rates at the bottom of the Skrwa valley based on C-14 dates, correlation of sediment (sed) and content of trace elements (te)

\begin{tabular}{|c|c|c|c|c|c|c|}
\hline \multirow[t]{2}{*}{ Location } & \multirow[t]{2}{*}{ Material } & \multirow{2}{*}{$\begin{array}{l}\text { Dating } \\
\text { method }\end{array}$} & \multirow{2}{*}{$\begin{array}{l}\text { Depth } \\
\text { cm }\end{array}$} & \multirow[t]{2}{*}{ Period } & \multicolumn{2}{|c|}{$\begin{array}{c}\text { Rate of deposition } \\
\text { mm/year }\end{array}$} \\
\hline & & & & & mean & $\min -\max$ \\
\hline $\begin{array}{l}\text { P1 } \\
\text { gully fan }\end{array}$ & $\begin{array}{l}\text { mineral } \\
\text { mineral } \\
\text { mineral } \\
\text { soil }\end{array}$ & $\begin{array}{c}\text { te, sed } \\
\text { te, sed } \\
\text { te, sed } \\
\text { C-14, sed }\end{array}$ & $\begin{array}{c}0-20 \\
20-60 \\
60-90 \\
90-120\end{array}$ & $\begin{array}{c}20^{\text {th }} \mathrm{c} . \\
16-19^{\text {th }} \mathrm{c} . \\
12-15^{\text {th }} \mathrm{c} . \\
220-1150 \mathrm{AD}\end{array}$ & $\begin{array}{l}2.00 \\
1.00 \\
0.86 \\
0.32\end{array}$ & $\begin{array}{c}0.63-1.40 \\
0.2-0.79\end{array}$ \\
\hline $\begin{array}{c}\text { P3 } \\
\text { palaoeochannel filling }\end{array}$ & $\begin{array}{c}\text { mineral (colluvium) } \\
\text { mineral-organic } \\
\text { mineral } \\
\text { organic }\end{array}$ & $\begin{array}{c}\text { te, sed } \\
\text { te, sed } \\
\text { C-14, te } \\
\text { C-14 }\end{array}$ & $\begin{array}{c}0-120 \\
120-210 \\
210-300 \\
300-355\end{array}$ & $\begin{array}{c}18-20^{\text {th }} c . \\
15-17^{\text {th }} c . \\
1150-14 / 15^{\text {th }} c . \\
1150 A D-2862 B C\end{array}$ & $\begin{array}{l}6.00 \\
3.00 \\
2.57 \\
0.13\end{array}$ & $\begin{array}{l}1.89-4.00 \\
0.11-0.14\end{array}$ \\
\hline $\begin{array}{c}\mathrm{P} 5 \\
\text { flood terrace }\end{array}$ & mineral-organic & $\begin{array}{c}\text { te } \\
\text { te } \\
\text { te } \\
\text { sed, te } \\
\text { C-14 }\end{array}$ & $\begin{array}{c}20 / 30 \\
30-70 \\
70-140 \\
140-180 \\
180-210\end{array}$ & $\begin{array}{c}20^{\text {th }} c . \\
18-19^{\text {th }} c . \\
15-17^{\text {th }} c . \\
12-15^{\text {th }} c \\
225 A D-1150 A D\end{array}$ & $\begin{array}{l}2.50 \\
2.00 \\
1.67 \\
1.14 \\
0.32\end{array}$ & $2.0-3.0$ \\
\hline
\end{tabular}

economic activity, their concentration has been reduced due to the significant share of "deeper layer" unpolluted deposits originating from erosion. Fig. $5 \mathrm{~A}$ presents the stages beginning from the Roman Era through the Migration Period, indicated as a reduction in the content of most analysed elements, followed by the early Middle Ages when economic growth was concentrated at Brudzeń and Parzeń, the two strongholds. Fluctuations in the upper part of the profile are supported by information regarding environmental changes. This area, according to historical sources (Tyszkiewicz 2003) and archival topographical maps (Fig. 2), was deforested and used intensively for agriculture. It is also possible to define deposit series related to the effects of land use changes corresponding to the last hundred years. The development of road traffic and the related emissions of combustion gas and other pollutants (e.g. particles from brake pads containing Cadmium) have led to an increase in the content of other elements, such as cadmium or lead (their presence is marked in the top layer of $20-40 \mathrm{~cm}$, fig. 5).

Considering the region's economic development, specific periods were correlated with peak concentrations of trace elements. The results shown in Fig. 5 and Table 2 confirm a much faster aggradation rate of colluvial sediments in historical times than older sediments, i.e. the bottom parts of the former Skrwa River meander.

The sediments in the Brudzeń Duży region are of neutral or alkaline $\mathrm{pH}$ (from $\mathrm{pH} 6.5$ to 8 ) so they are not prone to leaching. It would take a long time to remove the trace elements accumulated there. When it comes to mineralogy the sediments are highly homogenous. They consist mostly of quartz and clay minerals. There are some differences in granulometry but the samples for extraction were firstly sieved to separate the same fraction. The most prone to pollution are the clay minerals - their share in all the analysed samples was on a comparable level, from just a few to around $10-15 \%$ (so this factor can be omitted).

Transformation of slopes and the river valley (natural and anthropogenic conditions)

Based on the age of the analysed series determined using the radiocarbon method, the sedimentary and geochemical nature and sedimentation rate characteristics for the slopes and valley bottom were calculated (Fig. 6).

The rate of change from the moment of vegetation growth can be defined as slow, with most forms considered stable. The old river meanders were then filled with organic sediments, peat and organic mud (organic-mineral material). Such a slow aggradation can be estimated at $0.14 \mathrm{~mm}$ per year based on the meander near Krzyżanowo, which was cut off around 3104-2620BC.

A number of authors indicate increasing aggradation after deforestation, both on the bottom of dry valleys and in river valleys (Bork 1989; Dotterweich 2003; Klimek, 2002). Matter originating from soil erosion from the basin area is recorded in the type of sedimentation in the valley bottom (Starkel 1989; 2005; Reiß at al. 2009).

Near Brudzeń Duży the sedimentation rate changed around 66-384AD. Suspended material from the upland slopes was transported to the valley bottom during floods with an average annual accumulation range of around $0.3 \mathrm{~mm}$. The evidence of deforestation and usage of the slopes or outwash plains for agricultural purposes is well correlated with the archaeological data. In this period, the Wielbark (Przeworsk) culture settlements and agriculture were developing, beginning from the $2^{\text {nd }}$ century $A D$. Interpreting the geochemical data, an increase in the content of most analysed trace elements at $70 \mathrm{~cm}, 50 \mathrm{~cm}$ and $20-30 \mathrm{~cm}$ allows these layers to be correlated with the early Middle Ages, the Industrial Revolution and the fifty years after World War II, respectively. Based on the data, the above average aggradation intensity in the valley bottom has increased steadily from an average $0.3-1.15 \mathrm{~mm}$ per year in the Middle Ages to $1.67-2$ $\mathrm{mm}$ per year during the $17^{\text {th }}-19^{\text {th }}$ centuries and $2.5 \mathrm{~mm}$ per year during the last 100 years (Fig. 6).

Given that the meander cut-off period dates back to 3104BC$2620 \mathrm{BC}$, the process of filling with mostly organic matter for over 4000 years (until 1025AD-1275AD) can be estimated at an average of $0.13 \mathrm{~mm}$ per year. The meander's location quite far from the active river channel allows the assumption that only large floods could deposit suspended material here. The radiocarbon date of 208-545AD determined from the deposits filling the other meander (P11) confirms this assumption. It indicates a change in sedimentation, from organic to organic/ mineral, and an increase in the rate of meander filling, the average ranging from $1.3 \mathrm{~mm}$ to $1.67 \mathrm{~mm}$ per year. This organic/mineral character of the deposits dominated until the $3^{\text {rd }}-4^{\text {th }}$ centuries. (Fig. 5). Later the meanders were mostly filled with mineral sediments originating from erosion in gullies and eroded soil. This change in the type of sedimentation increased significantly in the cultivated area. 


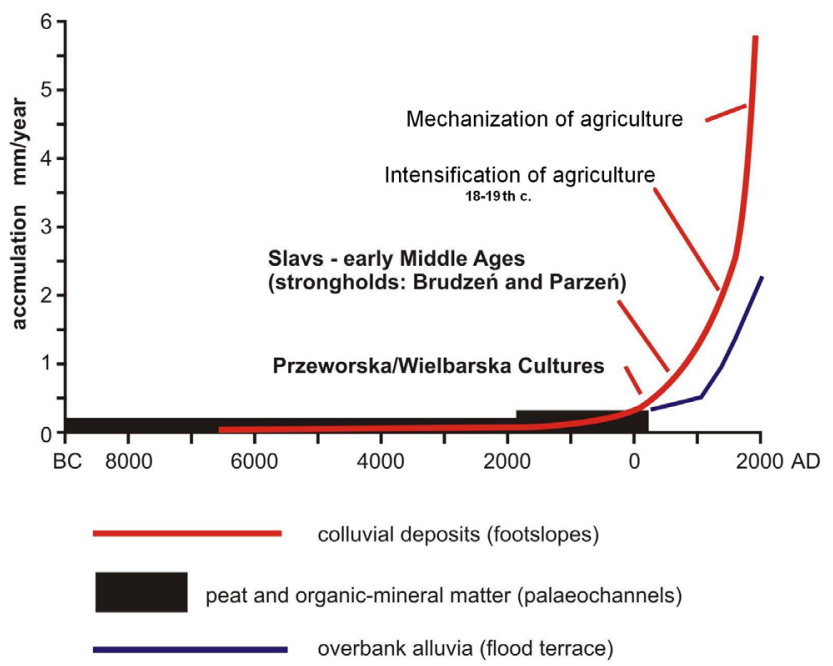

Figure 6. Accumulation rates of sediments on the bottom of the Skrwa valley vs. settlement and economic development stages in the region.

In the area of Brudzeń Duży, the suspended material from soil erosion and gullying has been deposited on the Skrwa valley bottom since 66-385AD. The C-14 dates determined for the proluvia bases, 206BC-645AD and 66-384AD, indicate stabilization of the incisions and progressive gullying. It took less than a hundred years for the first incisions on the slopes to become stable and turn into gullies. The erosion rate on deforested land was high in this period, the matter deposition intensity at gully mouths increased from 0.3 to $0.86 \mathrm{~mm}$ per year.

Detailed measurements of the gullies have not been taken. Generally, it was easily visible that the fans are small compared to the size of the gullies. Their volume is only $25-35 \%$ of the volume of the gullies. A high proportion of the eroded material due to gullying was taken away by fluvial transport.

Widespread deforestation is recorded on archival topographic maps in the Masovian region during the 19th and beginning of the 20th centuries (Fig. 2). This was also a period of increasing agricultural work, which coincides with an acceleration of denudation processes in the morainic plateau. Colluvial (deluvial) sedimentation at the bottom of the Skrwa River valley slope illustrates the existence of anthropopressure. In the period when the Brudzeń and Parzeń strongholds were operating, sedimentation exceeded $1 \mathrm{~mm}$ per year and, after the introduction of agricultural machines (mechanization), it reached $4-5 \mathrm{~mm}$ per year (Fig. 5).

\section{Conclusion}

The sedimentological and geochemical research carried out in the selected areas of north-western Mazovia allowed the determination of the following dynamic landscape systems and an analysis of their changes:

(1) The moraine plateu and slope denudation system with a colluvial subsystem;

\section{References}

Bork, HR 1989, 'Soil erosion during the past millennium in central Europe and its significance within the geomorphodynamics of the Holocene', Catena, Suppl., vol.15, pp. 121-131.

Buko, A 2005, Archeologia Polski Wczesnośredniowiecznej [Archaeology of Poland during early Middle Ages], Trio Press.

Dotterweich, M, Schmitt, A, Schmidtchen, U \& Bork, HR 2003,
(2) The river valley bottom system (filling of meanders, accumulation on the flood plain).

The environmental response to anthropogenic pressure was first expressed in the overchannel sediments on the Skrwa River valley bottom. Subsequently, the gully fans were formed. The age of organic deposits at the bottom of colluvia (proluvia) indicates that the period of gully formation in the post-glacial landscape ranged approximately from $66 A D$ to $545 A D$.

Geochemical and sedimentological features of deposits are particularly useful in separating the deposits characterized by substantial anthropopressure.

Based on C-14 dating, sedimentological and geochemical analysis of the deposits, aggradation intensity has been determined on the valley bottom at an average of $0.13 \mathrm{~mm}$ per year under natural conditions, and, along with growing anthropopressure, its increase from $1 \mathrm{~mm}$ per year at the beginning of the second millennium $B C$ to $2.5 \mathrm{~mm}$ per year over the last 100 years. In the examined area, the most intense changes, despite spatial limitations, have taken place on the slope system, where the denudation intensity from the beginning of deforestation for agricultural purposes to agricultural erosion increased from 0.3 $\mathrm{mm}$ per year to $6 \mathrm{~mm}$ per year.

\section{Acknowledgement}

The materials and data used in the article were prepared under the research project of the Ministry of Science and Higher Education number N N305 322135, entitled "Hierachical model of the natural system and its use for biodiversity assessment and forecasting". The authors give their appreciation to two anonymous referees for reviewing the manuscript, especially the second reviewer for his valuable comments and suggestions. 
Farkasa, A, Erraticob C \& Viganob L 2007, 'Assessment of the environmental significance of heavy metal pollution in surficial sediments of the River Po', Chemosphere, vol. 68, no. 4 , pp. $761-768$.

Folk, RL \& Ward, W 1957, 'Brazos Fiver bar: astudy in significance of grain size parameters', Journal Sed. Petrol., vol. 27, pp. 3-26.

Hildebrandt-Radke, I 2010, 'Pradziejowa antropopresja w dorzeczu środkowej Obry w okresie od V w.p.n.e. do VII w. n.e. i jej zapis w środowisku przyrodniczym w skali regionalnej i lokalnej, [Prehistory antropopressure in the catchment of middle Odra river from $5^{\text {th }}$ century $B C$ to $7^{\text {th }}$ century $A D$ and their record in environment in regional and local scale], Środowisko i kultura, vol. 8, pp. 51-55.

Kaczanowski, P \& Kozłowski, JK 1998, 'Wielka Historia Polski, Najdawniejsze dzieje ziem polskich (do VII w.). Tom 1'. [Great History of Poland. The earliest history of the Polish Land (to the 700AD). Vol.1], Fogra Press, Kraków..

Kalicki, T 2006, Zapis zmian klimatu oraz działalności człowieka i ich rola w holoceńskiej ewolucji dolin środkowoeuropejskich [Reflection of climate changes and human activity and their role in the holocene evolution of central European valleys], PAN IGiPZ, Warsaw.

Kittel, P, Forysiak, J, Błaszczyk, J, Cywa, K, Wacnik, A, Tomczyńska, Z, Muzolf, B \& Obremska M 2008, 'Przykłady oddziaływań społeczności pradziejowych na środowisko naturalne w rejonie Bechcic i Wierzbowej (Polska Środkowa)' [Examples of impact of prehistopric communities on the environment in the Bechcic and Wierzbowa area (central Poland)], Landform Analysis, vol.9, pp. 289-292.

Klimek, K 2003, 'Sediment transfer and storage linked to Neolithic and Early Medieval soil erosion in the upper Odra Basin, southern Poland' in Alluvial archaeology in Europe, eds AJ Howard, MG Macklin \& DG Passmore, Balkema, Rotterdam, pp.251-259.

Lang, A 2003, 'Phases of soil erosion derived colluviation in loess hills of South Germany', Catena, vol. 51, no 3-4, pp. 191-206.

Matusiak, K 2008, 'Pradzieje gminy Gozdowo' [Prehistory of Gozdowo community], in Śladami Franciszka Tarczyńskiego. Przeszłość gminy Gozdowo w świetle odkryć archeologicznych [Traces of Franciszek Tarczyński. Past community Gozdowo in the light of archaeological discoveries], ed T Kordala, Mazovian Museum in Płock, pp.17-26.

Niewiarowski, W 1995, Zarys zmian środowiska geograficznego na przykładzie okolic Biskupina [Outline of environmental changes on example of Biskupin area], Turpress, Toruń.

Ramsey, CB, Scott, M, van der Plicht, H 2013, 'Calibration for archaeological and environmental terrestrial samples in the time range $26-50$ ka cal BP', Radiocarbon, vol. 55, no 4, pp. 2029-2034.

Reimer, PJ, Bayliss, EBA, Beck, JW, Blackwell, PG, Ramsey, CB, Buck, CE, Cheng, H, Edwards, RL, Friedrich, M, Grootes, PM, Guilderson, TP, Haflidason, H, Hajdas, I, Hatté, C, Heaton, TJ, Hoffmann, DL, Hogg, AG, Hughen, KA, Kaiser, KF, Kromer, B, Manning, SW, Niu, M, Reimer, RW, Richards, DA, Scott, EM, Southon, JR, Staff, RA, Turney, CSM, van der Plicht, J 2013, 'IntCal13 and Marine13 Radiocarbon Age Calibration Curves 0-50,000 Years cal BP', Radiocarbon, vol. 55, no 4, pp. 1869-1887.

Reiß, S, Dreibrodt, S, Lubos, CCM \& Bork, HR 2009, 'Land use history and historical soil erosion at Albersdoft (northern Germany) - ceased agricultural land use after the prehistorical period, Catena, vol. 77, pp.107-118.
Sinkiewicz, M \& W Niewierowski (ed.) 1998, Rozwój denudacji antropogenicznej w środkowej części Polski północnej [Development of anthropogenic denudation in the central part of Northern Poland], Mikołaj Kopernik University Press, Toruń.

Smolska, E 2007, 'Development of gullies and sediment fans in last-glacial areas on the example of the Suwałki Lakeland (NE Poland)', Catena, vol. 71, pp. 122-131.

Smolska, E \& Szwarczewski, P 2012, 'Funkcjonowanie krajobrazu w świetle badań sedymentologiczno-geochemicznych na przykładzie wybranych obszarów NW Mazowsza' [Functioning of the landscape in the light of sedimentological and geochemical research - examples from NW Mazovia], in Model funkcjonalny systemu krajobrazowego [Functional model of the landscape system], eds A Richling \& J Lechnio, WGSR UW, Warsaw, pp. 117-148.

Stankoviansky, M 2003, 'Historical evolution of permanent gullies in the Myjava Hill Land, Slovakia', Catena, vol. 51, pp. 223239.

Starkel, L 2005, 'Antrophogenic soil erosion since the Neolithic in Poland', Z. Geomorph. N.E., Suppl. vol. 139, pp. 189-201.

Starkel, L 1989, 'Antropogeniczne zmiany denudacji i sedymentacji w holocenie na obszarze Europy Środkowej' [Anthropogenic changes of denudation and sedimentation during Holocene in the middle Europe], Przegląd Geogr., vol. 61, pp. 33-49.

Szpikowski, J 2010, 'Antropogeniczne przekształcenia rzeźby zlewni Perznicy w neoholocenie (Pojezierze Drawskie, dorzecze Parsęty)' [Anthropogenic transformation of relief in Perznica catchment during Neoholocene], Seria Geografia, vol. 91, Adam Mickiewicz University Press.

Szwarczewski, P 2005, 'Geochemiczny i paleogeograficzny zapis dynamiki procesów rzeźbotwórczych w holocenie na przykładzie stoków w okolicach Płocka' [Geochemical and palaeogeographical record of relief transformation processes and their dynamics in the Płock area], in Z problematyki funkcjonowania krajobrazów nizinnych [On the issue of the functioning of lowland landscapes], eds A Richling \& J Lechnio, WGSR UW Press, pp.77-89.

Szwarczewski, P 2009, 'Wpływ zasiedlenia Mazowsza (od średniowiecza po czasy współczesne) na formy i procesy geomorfologiczne na przykładzie doliny dolnego Świdra' [Geomorphological responese to the historical settlemnet of Mazivia from Medieval till today (on example of Lower Świder area], in 'Środowiskowe uwarunkowania lokalizacji osadnictwa' [Enviromnetal conditions of settlements], eds L Domańska, P Kittel \& J Forysiak, Środowisko-CzłowiekCywilizacja, vol. 2, pp. 347-353.

Twardy, J 1995, 'Dynamika denudacji holoceńskiej w strefie krawędziowej Wyżyny Łódzkiej' [The Dynamics of Holocene denudation in the Łódź Region], Acta Geogr. Lodz., vol. 29.

Tyszkiewicz, J 2003, 'Krajobrazy Mazowsza w ostatnim tysiącleciu" [Landscapes of Mazovia in the last milennium], in Przyroda Mazowsza i jej antropogeniczne przekształcenia [Landscape of Mazovia and its anthropogenic transformations], ed A Richling, WSH Pres, Pułtusk, pp. 211-230.

Zolitschka, B, Behre, KE \& Schneider, J 2003, 'Human and climate impact on environment as derived from colluvial, fluvial and lacustrine archives - examples from the Bronze Age to the migration period, Germany', Quaternary Science Reviews, vol. 22, pp. 81-100. 